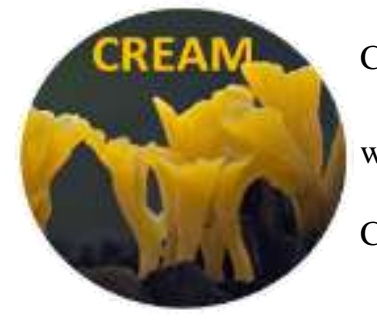

Current Research in Environmental \& Applied Mycology 5 (2): 145-148(2015) ISSN 2229-2225

www.creamjournal.org

Article

CREAM

Copyright (C) 2015

Doi 10.5943/cream/5/2/8

\title{
A new Gyalidea species (Ascomycota: Solorinellaceae) from India
}

\section{Gupta $\mathbf{P}^{1,2^{*}}$ and Sinha $G \mathbf{P}^{1}$}

\author{
${ }^{1}$ Botanical Survey of India, Central Regional Centre, Allahabad-211002, India \\ ${ }^{2}$ Department of Botany, Devi Ahilya Vishwavidyalaya, Indore-452001, India
}

Gupta P, Sinha GP 2015 - A new Gyalidea species (Ascomycota: Solorinellaceae) from India. Current Research in Environmental \& Applied Mycology 5(2), 145-148, Doi 10.5943/cream/5/2/8

\begin{abstract}
Gyalidea corticola sp. nov. (Solorinellaceae) is described as a new species from India. The species is characterized by its pale brownish apothecia, submuriform ascospores and habitat preference.
\end{abstract}

Key words - lichen - Ostropales - Sikkim - taxonomy

\section{Introduction}

The Genus Gyalidea Lett. ex Vězda is a widespread genus of family Solorinellaceae comprises 64 species world wide (Kirk \& Cooper 2009). The genus is characterized by gyalectoid apothecia, non-amyloid hymenium, simple, septate paraphyses and hyaline, submuriform or transversely septate ascospores. Most of the species of the genus grow on soil, rocks, mosses or on plant debris, except G. minuta Boom \& Vědza and G. fruticola Svensson \& Thor which occur on tree bark. A third new corticolous species collected for Sikkim, India is being described as Gyalidea corticola.

\section{Materials \& methods}

The new species is described based on the specimen collected from the Sikkim, India. Identification work was carried out in the Lichenology Laboratory, Botanical Survey of India, Central Regional Centre, Allahabad. The images displayed in Figs. 1 \& 2 were obtained with stereomicroscope (Olympus SZ61) and compound microscope (Nikon Eclipse 50i). Sections of thalli and ascomata were mounted in water, $10 \% \mathrm{KOH}$, and Lugol's iodine solution. All measurements were made in water. Spore measurements are given as (the minimum value recorded-) (mean value - standard deviation) - (mean value + standard deviation) (-the maximum value recorded). The mean value $(\bar{X})$, the standard deviation (s.d.) and the total sample size $(n)$ is given in parentheses. Chemical constituents were identified by thin-layer chromatography in solvent $\mathrm{C}$ (170 $\mathrm{ml}$ toluene, $30 \mathrm{ml}$ glacial acetic acid) according to standardized methods (Orange et al. 2001). Voucher specimen is deposited in the herbarium of Botanical Survey of India, Central Regional Centre, Allahabad (BSA). 


\section{Results}

\section{Taxonomic discriptions}

Gyalidea corticola Pooja Gupta \& G.P. Sinha, sp. nov.

Figs. 1 \& 2 MycoBank No.: MB 812992.
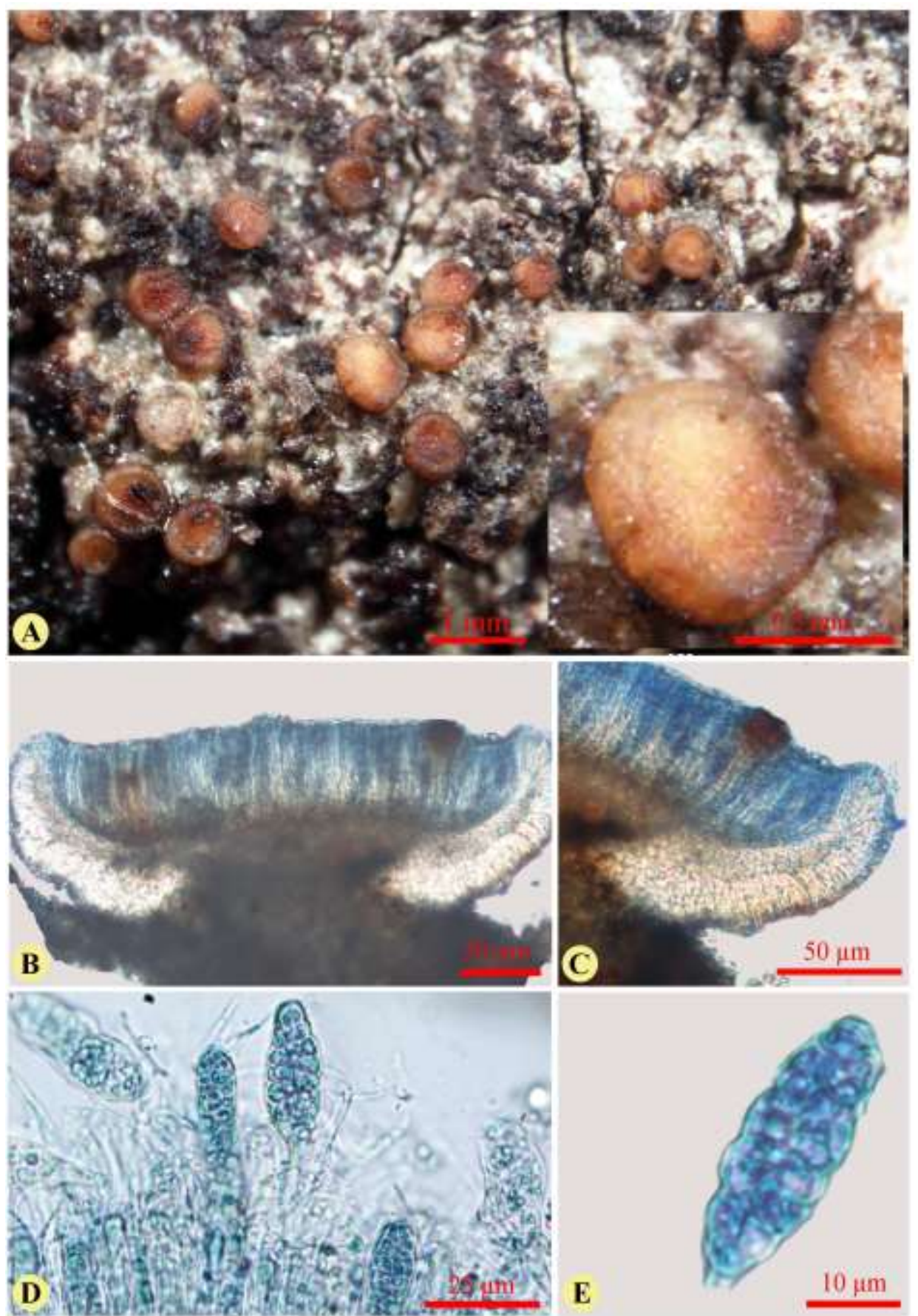

Fig. 1 - Gyalidea corticola, A, habit. B \& C, vertical section of apothecium. D \& E, ascospores. 
Etymology - The specific epithet 'corticola' refers to the substrate.

Thallus crustose, corticolous, rimose-areolate, cracked, rough, up to $6 \mathrm{~cm}$, grey greenishbrown. Isidia and soredia not seen. Photobiont green-alga, cells 8-12 $\mu \mathrm{m}$ diam.

Apothecia numerous, rounded, adnate to sessile, constricted at base, $0.4-0.8 \mathrm{~mm}$ diam., 155-160 $\mu \mathrm{m}$ high and 354-408 $\mu \mathrm{m}$ wide, yellowish-brown, translucent when wet, without thalline margin; disc concave to almost flat; margin smooth, entire, concolorous with disc; exciple well developed, 15-35 $\mu \mathrm{m}$ wide, brownish; epithecium hyaline, indistinct; hymenium hyaline, 40-50 $\mu \mathrm{m}$ high, I-, KI+ slightly blue; hypothecium pale brownish, 20-40 $\mu \mathrm{m}$ thick; paraphyses simple, rarely sparsely branched and anastomosing, distinctly septate, $0.87-1.20 \mu \mathrm{m}$ thick; asci clavate, 2-4 spored, 55-78 × 15-18 $\mu \mathrm{m}$; ascospores hyaline, narrowly ellipsoidal, ends acute, submuriform, 5-7 transverse septa and 0-2 longitudinal septa, (27-)29-37(-43) $\times(9-) 9-15(-17) \mu \mathrm{m}$ (length: $\bar{X}=$ $33.42 \mu \mathrm{m}$, s.d. $=4.17 \mu \mathrm{m}, \mathrm{n}=8$; width $\bar{X}=12.64 \mu \mathrm{m}$, s.d. $=3.16 \mu \mathrm{m}, \mathrm{n}=8$ ), without a distinct perispore.
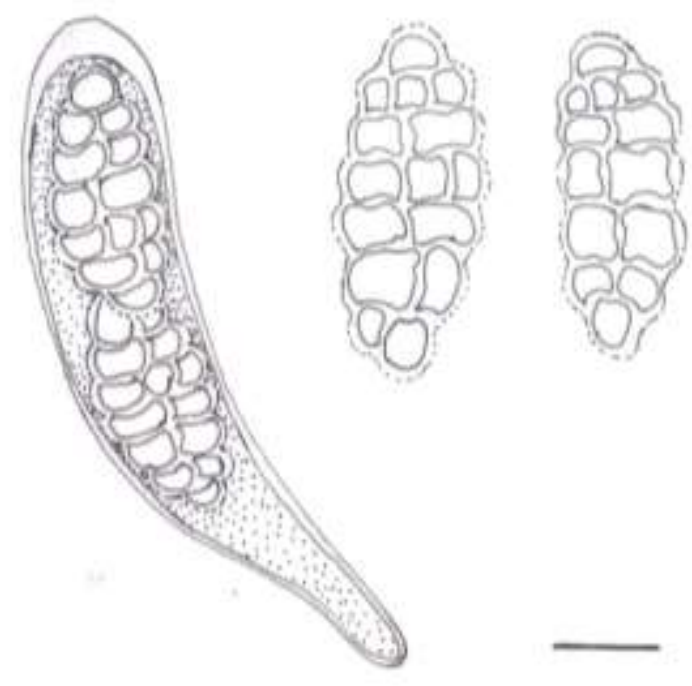

Fig. 2 - Gyalidea corticola, asci and ascospores. $-\quad$ Bar $=10 \mu \mathrm{m}$.

Chemistry - Thallus $\mathrm{K}-, \mathrm{C}-, \mathrm{KC}-, \mathrm{P}-$; hymenium (hymenial gelatin, paraphyses, asci) I-, KI+ slightly blue.

Distribution - Known only from the type collection.

Specimen examined - India, Sikkim: Penangla $\left(27^{\circ} 22^{\prime \prime} \mathrm{N}, 88^{\circ} 36^{\prime \prime}\right.$ E), c. $1880 \mathrm{~m}$. alt., on the bark of a tree, 19 November 2006, G.P.Sinha 3597 (Holotype-BSA).

Notes - Among the corticolous species of this genus, Gyalidea corticola resembles $G$. minuta Boom \& Vědza and G. fruticola Svensson \& Thor, in having brownish apothecia and submuriform ascospores. However, it differs from both the latter species in the size of apothecia and larger ascospores. The Apothecia of Gyalidea corticola is $0.4-0.8 \mathrm{~mm}$ in diam, whereas it is $0.15-0.2 \mathrm{~mm}$ and $0.1-0.3 \mathrm{~mm}$ diam. in G. minuta. and G. fruticola respectively. Similarly ascospores of Gyalidea corticola are 20-30 × 5-15 $\mu \mathrm{m}$ whereas ascospores are 12-15 $\times 5-9 \mu \mathrm{m}$ and 17-23 × 5-9 $\mu \mathrm{m}$ in G. minuta and in G. fruticola respectively (Boom, P.P.G. van den \& Vězda, A. 1995; Svensson M, \& Thor G. 2007). 
Among non-corticolous Gyalidea species, it is somewhat similar to G. subscutellaris (Vězda) Vězda and G. psammoica (Nyl.) Lettau ex Vězda, due to their darker apothecia but Gyalidea subscutellaris has smaller apothecia $0.2-0.3 \mathrm{~mm}$ diam and ascospores $(16-20 \mu \mathrm{m})$ and grows on bryophytes, while G. psammoica also has smaller ascospores $(14-18 \mu \mathrm{m})$ and grows on sandy soil (Vězda 1966).

\section{Acknowledgements}

We are thankful to Dr. Paramjit Singh Director, Botanical Survey of India, Kolkata for facilities and to Ministry of Environment, Forests \& Climate Change (MoEFCC), New Delhi for financial assistance under Flora of India Project.

\section{References}

Boom PPG van den \& Vězda A. 1995 - A new species and a new variety of the lichen genus Gyalidea from Western Europe. Mycotax on 54: 421-426.

Kirk PM \& Cooper J. 2009 - CABI Bioscience database: Index fungorum.

[http://www.indexfungorum.org/Names/Names.asp (viewed online on 20 November 2014)]

Orange A, James PW \& White FJ. 2001 - Microchemical methods for the identification of lichens. British lichen Society, London.

Svensson M \& Thor G. 2007 - Gyalidea fruticola, a new corticolous lichen from Europe. Lichenologist 39(4): 335-338.

Vězda A. 1966 - Flechtensystematische studien IV. Die Gattung Gyalidea Lett. Folia Geobot. Phytotax., Praha, 1(4): 311-340. 